Taxonomy and systematics

\title{
A new amphipod species (Peracarida: Amphipoda: Ampithoidae) collected from Cenote Aerolito, Cozumel Island, Quintana Roo
}

\author{
Una especie nueva de anfípodo (Peracarida: Amphipoda: Ampithoidae) recolectado del cenote \\ Aerolito, isla Cozumel, Quintana Roo \\ Manuel Ortiz, Ignacio Winfield* \\ Laboratorio de Crustáceos, Facultad de Estudios Superiores Iztacala, Universidad Nacional Autónoma de México, \\ Av. de los Barrios 1, Los Reyes Iztacala, 54090 Tlalnepantla, Estado de México, Mexico \\ Received 10 February 2014; accepted 2 February 2015 \\ Available online 28 May 2015
}

\begin{abstract}
A new species of amphipod belonging to the family Ampithoidae was collected from Cenote Aerolito, Cozumel Island, Quintana Roo associated with a macroalgae bed. The main differences between the new species and the previously recorded species in the Gulf of Mexico and Caribbean Sea, Cymadusa compta and Cymadusa setosa respectively, are also presented. The new species increases the globally described number of $C y m a d u s a$ species to 33 .

All Rights Reserved (C) 2015 Universidad Nacional Autónoma de México, Instituto de Biología. This is an open access item distributed under the Creative Commons CC License BY-NC-ND 4.0.
\end{abstract}

Keywords: Crustacea; Ampithoidae; Cymadusa; Anchialine system; Mexican Caribbean

\section{Resumen}

Se describe una especie nueva de anfípodo de la familia Ampithoidae recolectada de macroalgas del Cenote Aerolito, Isla Cozumel, Quintana Roo. Se presentan las principales diferencias entre la especie nueva y las especies previamente documentadas para el golfo de México y el mar Caribe, $C$. compta y $C$. setosa. Esta especie nueva incrementa el número de especies de Cymadusa a 33 a nivel global.

Derechos Reservados (C) 2015 Universidad Nacional Autónoma de México, Instituto de Biología. Este es un artículo de acceso abierto distribuido bajo los términos de la Licencia Creative Commons CC BY-NC-ND 4.0.

Palabras clave: Crustacea; Ampithoidae; Cymadusa; Sistema anquialino; Caribe mexicano

\section{Introduction}

The Yucatán Peninsula represents a large karstic environment that has a great variety of epigean systems or "cenotes" (sinkholes). The majority of these are connected with the sea, producing a bi-layered ecosystem: a surface layer of freshwater and an underlying seawater layer (Suárez-Morales \& RiveraArriaga, 1998). Faunal dispersal and speciation mechanisms are

\footnotetext{
* Corresponding author.

E-mail address: ignacioc@unam.mx (I. Winfield).

Peer Review under the responsibility of Universidad Nacional Autónoma de México.
}

poorly known in these karstic ecosystems; however, allopatric speciation by vicariance processes has been documented in many anchialine crustaceans. As a consequence, geographic and reproductive isolations occur inside the cenotes, increasing thus the endemism rate and regional biodiversity hotspots (Álvarez, Villalobos, \& Iliffe, 2010; Holsinger, 1992; Iliffe, 1992; Jaume, Iliffe, \& van Der Ham, 2013).

The studies on crustaceans that occur exclusively in the subterranean marine environments of the Yucatán Peninsula include some groups with high endemism rates: Peracarida, Copepoda, Decapoda, and Branchiopoda; particularly, studies on stygobiont crustaceans from cenotes in Cozumel Island (Quintana Roo, Mexico) are scarce and the few existing ones 
have focused on cladocerans, copepods (Gutiérrez-Aguirre, \& Cervantes-Martínez, 2008), peracarids, and decapods (Iliffe, 1992; Mejía-Ortiz, López-Mejía, \& Muñoz-Gómez, 2008). Previously, 4 amphipods (Bahadzia bozanici Holsinger, 1992; Melita longisetosa Sheridan, 1980; Melita planaterga Kunkel, 1910; and Parhyale hawaiensis Dana, 1853) and a tanaid (Hargeria rapax Harger, 1879) were documented from Cenote Aerolito, Quintana Roo, Mexico (Trujillo-Pisanty, ChávezSolis, Solis-Weiss, \& Hermoso-Salazar, 2010).

A revision of the Cymadusa species complex, with the description of 10 new species from Australian waters, increased the number of species in this genus to 32 (Hughes \& Lowry, 2009; Peart, 2004, 2007; Peart \& Hughes, 2014). In this study a new species of Cymadusa (Amphipoda: Ampithoidae) collected from Cenote Aerolito, Cozumel Island, Quintana Roo is described, raising the total number of species in the genus to 33 . It is the third species of the genus known in the Gulf of Mexico and Caribbean Sea.

\section{Materials and methods}

Cenote Aerolito is located in Cozumel Island $\left(20^{\circ} 27^{\prime} 58^{\prime \prime} \mathrm{N}\right.$, $86^{\circ} 58^{\prime} 41^{\prime \prime} \mathrm{W}$ ), north-northwestern (NNW) Caribbean Sea. It is characterized by a $71 \mathrm{~m} \times 21 \mathrm{~m}$ anchialine pool, which is $6 \mathrm{~m}$ deep. The cenote is bordered by Rhizophora mangle; it has a rocky bottom and macroalgae as the main substrate (TrujilloPisanty et al., 2010). This cenote is connected to the Caribbean Sea via channels and undergound passages (Yánez, ZarzaGonzález, \& Mejía-Ortiz, 2008).

Samples of macroalgae were collected manually at a depth of $1.5 \mathrm{~m}$, and then, $5.0 \mathrm{ml}$ of an alcohol/formalin (1:1) solution was added to the sample; this aids to separate crustaceans from the algae. Subsequently, the specimens were sieved through a $0.4 \mathrm{~mm}$ mesh and preserved in $70 \%$ ethanol. Specimens of the new species were examined, dissected, and illustrated in detail using a dissecting MOTIC SMZ-168 and MOTIC BA-210 compound microscopes, both equipped with a camera lucida. Figures were completed using Corel Draw V.12. The terminology used for structures and setae/spines, and in the description, remarks, and morphological comparisons is that of Bousfield (1973) and Ledoyer (1986). The classification system of Lowry and Myers (2013) was adopted in this study. The type specimens are deposited in the Colección Nacional de Crustáceos (CNCR), Instituto de Biología, UNAM, Mexico.

\section{Description}

Order Amphipoda Latreille, 1816

Suborder Senticaudata Lowry \& Myers, 2013

Infraorder Corophiida Leach, 1814

Parvorder Corophiidira Lowry \& Myers, 2013

Superfamily Corophioidea Leach, 1814

Family Ampithoidae Stebbing, 1899

Genus Cymadusa Savigny, 1816

Cymadusa herrerae n. sp. (Figs. 1-3)

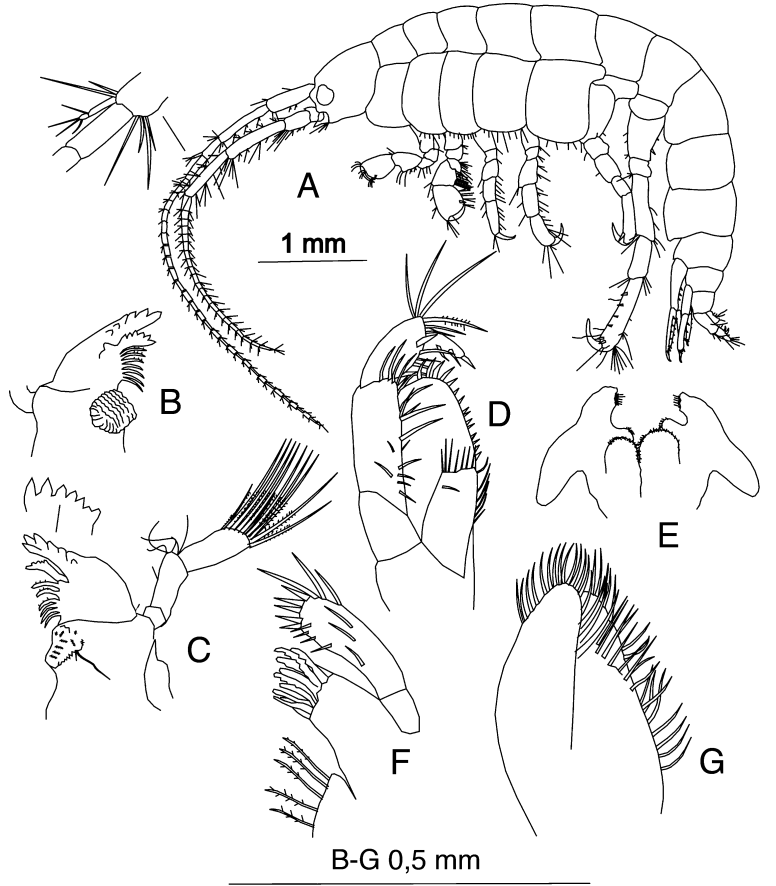

Figure 1. Cymadusa herrerae n. sp., female holotype: (A) lateral view of body; (B) right mandible; (C) left mandible; (D) maxilliped; (E) lower lip; (F) maxilla $1 ;(\mathrm{G})$ maxilla 2 .

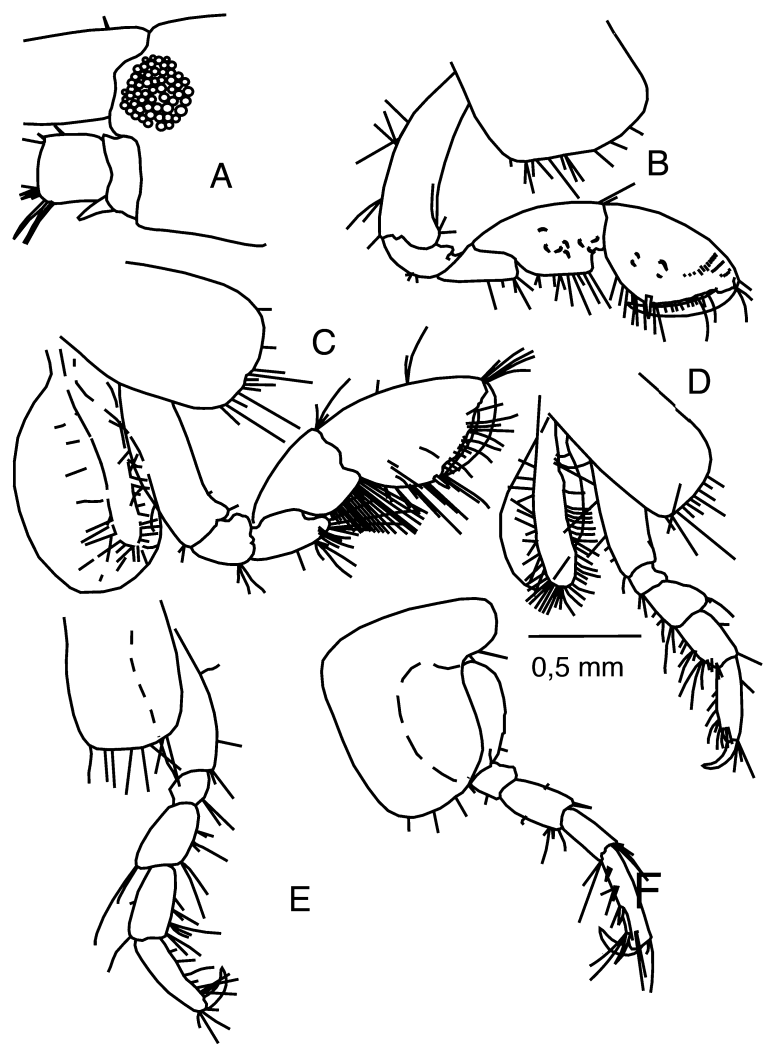

Figure 2. Cymadusa herrerae n. sp., female holotype: (A) lateral view of head; (B) gnathopod 1; (C) gnathopod 2; (D) pereopod 3; (E) pereopod 4; (F) pereopod 5 . 


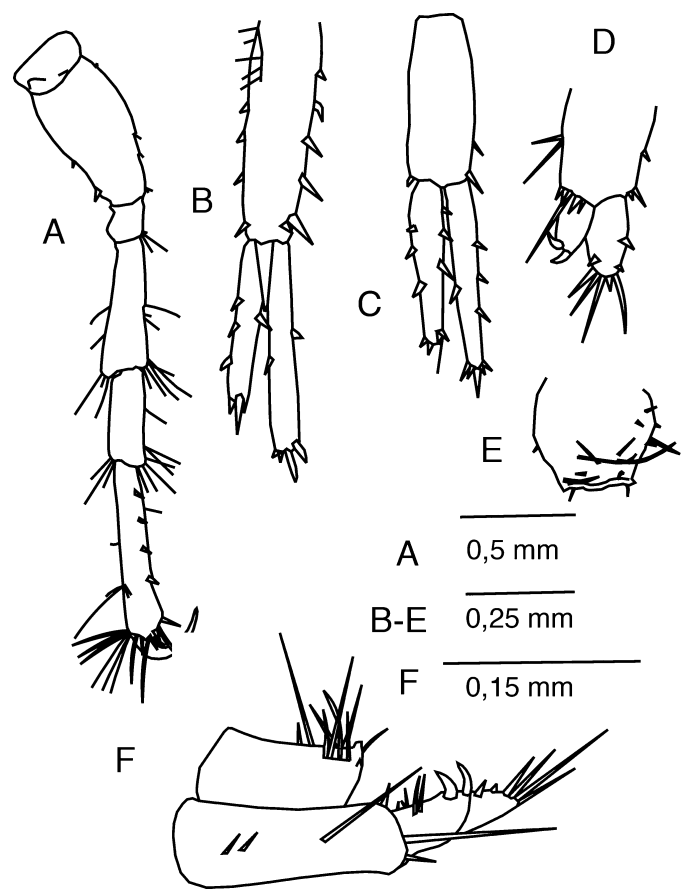

Figure 3. Cymadusa herrerae n. sp., female holotype: (A) pereopod 7; (B) uropod 1; (C) uropod 2; (D) uropod 3; (E) telson; (F) lateral view of uropod 3 and telson.

\section{Diagnosis}

Eye with ommatidia devoid of color; anteriorly concave cephalic lobe; antenna 1 reaching pereonal segment 6 of body; antennal gland well developed on base of antenna 2; outer lobe of maxilla 2 widest proximally; coxa 1 with sparse setae on ventral margin; gnathopods 1-2 with article 6 larger than 5, each with palmar robust setae; article 2 anterior margin on gnathopod 1 with 2 distal setae; gnathopod 2 article 5 posterior lobe with dense tuft of parallel, long setae; pereopod 5 reaching proximal half of article 5 of pereopod 7; pereopod 5 article 6 posterior margin devoid of setae; uropod 1 interramal spine 0.5 times as long as outer ramus; telson truncate distally; uropod 3 peduncle longer than rami; inner ramus longer than outer one, with 2 robust setae on inner ramus, a tuft of 4 setae and 1 robust seta distally on inner ramus; tip of outer ramus with 2 hooks turned downward; telson truncate distally.

Holotype, adult female (CNCR 28285); body length $7.7 \mathrm{~mm}$. Lateral view (Figs. 1A and 2A). Rostrum lacking; eye almost round, with more than 50 ommatidia; cephalic lobe anterior margin clearly concave; coxae 1-5 wide and deep; coxa 5 deepest, bearing small posterior lobe; coxae 1-5 ventral margin covered with sparse setae; coxae 6 and 7 very small.

Antennae (Fig. 1A): antenna 1 reaching pereonal segment 6; article 1 shorter than head; article 2 longer than 1; article 3 less than half-length of 2; accessory flagellum 2-articulate, article 2 vestigial, 0.6 times as long as article 1 of flagellum; flagellum 33-articulate, each article with 2 short setae above and 1 below. Antenna 2 shorter than 1; antennal gland well developed; peduncle article 4 longer than 5; flagellum 22-articulate, longer than length of articles $1-5$ of peduncle combined.
Mouthparts (Fig. 1B-G): mandibles with well-developed molar process; palp inserted at same level as molar, 3-articulate, article 1 short, article 2 with a subdistal and 5 distal setae, article 3 bearing 10 distal long setae. Right mandible with 6 incisors, lacinia mobilis with 6 teeth, spine row with 7 accessory setae; left mandible with 7 incisors, lacinia mobilis with 5 teeth, spine row with 6 accessory setae. Maxilliped inner lobe narrower than outer one, with 7 distal and 6 inner marginal setae; outer lobe 2 times longer than inner one, with 13 marginal setae; palp article 2 with 10 long marginal setae, and 2 submarginal ones; article 3 half-length of article 2, with 1 robust, 6 simple and 1 pectinate setae distally; article 4 shorter than 3 , with 1 distal and 2 subdistal setae. Lower lip with mandibular lobes well developed; outer lobes with typical inner notch on "shoulders"; inner lobe rounded, covered with small setae distally. Maxilla 1 inner lobe with 5 plumose setae; outer lobe bearing 9 robust setae; palp 2-articulate, article 2 with 12 distal, 3 subdistal, and 3 medial setae. Maxilla 2 inner lobe widest proximally, with 17 long setae distally; outer lobe covered with 15 marginal setae and 7 facial setae.

Gnathopods (Fig. 2B-C): ventral margin of coxa 1 with sparse setae; gnathopod 1 smaller than 2; article 2 posterior margin with few long setae; anterodistal corner with 2 small ones; articles 3-4 subequal in length; article 4 with posterior right angled lobe; article 5 shorter and narrower than 6 , with posterior rectangular lobe bearing 5 long and 5 short setae; article 6 subtriangular, palm oblique, margin defined with a strong robust seta, covered with 4 long and 14 short setae, dactylus surpassing palm slightly. Gnathopod 2 article 2 posterior margin with 6 short setae; distal anterior margin bearing 1 distal and 1 subdistal small setae; article 4 forming round posterior lobe, covered with 2 tufts of setae; article 5 posterior rectangular lobe lined with long parallel setae; article 6 longer than 5; palm oblique, defined with a strong robust seta and a small notch; with 15 marginal setae.

Pereopods (Figs. 2D-F and 3A): pereopod 3 article 2 as long as 3-5 combined, with 2 long and 3 short setae on posterior margin; article 4 shorter than 5 , with small lobe on anterior margin, with 1 long and 4 short setae on posterior margin, and 1 short and 1 long seta on tip of anterior lobe; article 5 bearing 2 setae on anterior margin, and 6 short and 5 long setae on posterior margin; article 6 longer than 5, with 1 seta on anterior margin, 5 on posterior margin and 3 on anterodistal corner; dactylus less than half-length of article 6, naked. Pereopod 4 similar to 3 , except article 4 anterior lobe bigger. Pereopod 5 article 2 wide and rounded, with 1 robust seta at posterodistal margin; article 4 longer than 5 , with 1 posterodistal and 4 anterodistal setae; article 5 shorter than 6 , with long seta on posterior margin and 2 on anterior one; article 6 as long as article 2, with 4 robust setae on anterior margin, 1 big and 1 small setae on posterodistal corner and 4 long subdistal setae; dactylus curved and short. Pereopod 6 missing in the holotype. Pereopod 7 article 2 narrow, as long as articles 3 and 4 combined; with 4 short setae on posterior margin and 2 robust setae on anterior one; article 4 longer than 5, with tuft of 3 setae midway and another of 5 long setae on posterodistal corner; with 2 setae midway and 2 long and 1 short setae on anterodistal corner; article 5 with 
a tuft of 7 setae on posterodistal corner and 3 on anterodistal one; article 6 longest, with 8 robust setae on posterior margin, 3 long distal setae and another 6 on anterodistal corner; dactylus curved and shorter than half-length of article 6.

Uropods (Fig. 3B-D and F): uropod 1 inner margin of peduncle with 6 robust setae; outer with 4; distoventral spur less than half-length of outer ramus; outer ramus with 3 robust setae on outer margin, 1 on inner margin, and 1 long and 1 short distal robust setae; inner ramus with 1 robust setae midway on both inner and outer margins, and 2 long and 2 short robust setae distally. Uropod 2 inner margin of peduncle with 2 subterminal robust setae; outer margin with 1 distal robust seta; outer margin of outer ramus with 3 robust setae, 1 long seta and 2 short robust setae distally; 3 robust setae on inner and outer margins; outer margin of the inner ramus with 1 midway robust setae, 2 long and 4 short distal robust setae, and 3 robust setae on inner margin. Uropod 3 peduncle longer than rami; inner ramus longer than outer, with 2 robust setae on inner ramus, a tuft of 4 setae and 1 robust seta distally on inner ramus; tip of outer ramus with 2 hooks turned downward.

Epimera (Fig. 1A) 1-3 naked; epimeron 3 posteroventral angle slightly produced.

Telson (Fig. 3E and F) as long as wide; distal margin truncate and sinuous, with 1 upturned tooth on each distal corner, 2 long subdistal setae and some others submarginally inserted.

Gills (Fig. 2C and D) plates smooth, large, concave-convex, rounded on coxa 1 and ovoidal on coxae 3-6.

Oostegites (Fig. 2C and D) on coxa 2 and 3 margins lined with long setae, as long as article 2 of gnathopod 2 and pereopod 3 .

\section{Taxonomic summary}

Type locality

Cenote Aerolito, Cozmel Island, Quintana Roo, Mexico.

\section{Material examined}

Holotype: female with well-developed oostegites (used for drawings); $7.7 \mathrm{~mm}$ total length (CNCR 28285); Cenote Aerolito, Cozumel Island, Quintana Roo, Mexico; $1.5 \mathrm{~m}$ depth, 25 June 2012; colls. I. Winfield and M.A. Lozano-Aburto. Additional material: a damaged female, collected in the same sample as the holotype female.

\section{Etymology}

The new species is named after María Teresa Herrera Dorantes, Benthos Laboratory, CINVESTAV-Unidad Mérida, Yucatán.

\section{Remarks}

Cymadusa herrerae n. sp. is morphologically similar to Cymadusa compta. The female of the new species differs from the female of $C$. compta by having an eye with ommatidia devoid of color (ommatidia light reddish in C. compta); a concave anterior cephalic lobe (slightly rounded in C. compta); antenna 1 reaching pereonal segment 6 of body (surpassing pleonal segment 2 in C. compta); antennal gland well developed on the base of antenna 2 (poorly developed in C. compta); inner lobe of maxilla 2 widest proximally (widest medially in $C$. compta); gnathopods 1 and 2, article 6 larger than 5 (as long as 5 in C. compta); article 2 posterior margin on gnathopod 1 with 4 5 setae (completely covered with setae in C. compta); gnathopod 2 article 5, anterior lobe devoid of setae (covered with long setae in $C$. compta); gnathopod 2 article 5, posterior lobe with dense tuft of parallel and long setae (lacking in C. compta); pereopod 5 article 6, posterior margin devoid of setae (with 3 tufts of setae in C. compta); uropod 3 outer margin with 2 setae (45 setae in $C$. compta); uropod 1 , distoventral spur almost reaching halfway along the outer ramus (not reaching halfway along the outer ramus in $C$. compta); telson distally truncate (rounded in $C$. compta). Finally, the habitat of $C$. herrerae n. sp., is mud with macroalgae on the bottom at Cenote Aerolito, but that of C. compta is mainly seagrass on shallow waters (Bousfield, 1973; Ledoyer, 1986).

The new species $C$. herrerae differs from Cymadusa setosa (Peart, 2004) in having a first antenna shorter than body length (as long or longer in C. setosa); sparse setae on posterior margin of articles 5-6 on gnathopod 1 (densely setose in C. setosa); article 4 forming short posterior lobe (longer in C. setosa); article 5 as long as 6 (article 5 much shorter than 6 in $C$. setosa); coxa 4 anteroventral corner rounded (right angle in $C$. setosa). Finally, the new species $C$. herrerae n. sp. is a smaller species than C. setosa.

Prior to this study, 212 species belonging to 6 different groups of crustaceans had been documented from the subterranean karstic ecosystems, including the cenotes of the Yucatán Peninsula, Mexico: Remipedia (2 species), Ostracoda (2 species), Peracarida (24 species, grouped in amphipods, isopods, tanaids, mysids, and thermosbaenaceans), Decapoda (60 species), Copepoda (61 species), and Branchiopoda (63 species). Therefore the new species described in this study increases the number of Yucatán crustaceans to 213 and 25 species of peracarids in karstic systems from SE Mexico.

\section{Acknowledgements}

To Universidad Nacional Autónoma de México for the funds obtained through grants PAPIME-PE207311 and PAPIIT-IN229011. Also, the project PAPCA 2014, FESI-DIPPAPCA-2014-20. We thank the authorities of Conapesca DGOPA (02921.290411.1172) from the Agriculture and Fisheries Secretariat (Sagarpa), and Universidad de Quintana Roo, Unidad Académica Cozumel, Cuerpo Académico Manejo y Conservación, for support during "The II Peracarid Crustaceans Meeting-2012".

\section{References}

Álvarez, F., Villalobos, J. L., \& Iliffe, T. M. (2010). A new species of mud shrimp of the genus Espeleonaushonia (Decapoda: Gebiidea: Laomediidae) from Palau. Zootaxa, 2429, 61-68.

Bousfield, E. L. (1973). Shallow water Gammaridean Amphipoda of New England. London: Cornell University Press. 
Gutiérrez-Aguirre, M. A., \& Cervantes-Martínez, A. (2008). Cladóceros y copépodos dulceacuícolas. In L. M. Mejía-Ortiz (Ed.), Biodiversidad acuática de la isla de Cozumel (pp. 121-149). Madrid: Plaza y Valdés.

Holsinger, J. R. (1992). Two new species of the subterranean amphipod genus Bahadzia (Hadziidae) from the Yucatán Peninsula region of southern Mexico, with an analysis of phylogeny and biogeography. Stygologia, 7, 85-105.

Hughes, L. E., \& Lowry, J. K. (2009). Ampithoidae. In J. K. Lowry, \& A. A. Myers (Eds.), Benthic Amphipoda (Crustacea: Peracarida) of the Great Barrier Reef (vol. 2260) (pp. 153-219). Australia: Zootaxa.

Iliffe, T. M. (1992). An annotated list of the troglobitic anchialine and freshwater fauna of Quintana Roo. In D. Navarro, \& E. Suárez-Morales (Eds.), Diversidad biológica en la Reserva de la Biosfera de Sian Ka'an, Quintana Roo, México (pp. 197-213). Chetumal: Centro de Investigaciones de Quintana Roo (CIQRO)/SEDESOL.

Jaume, D., Iliffe, T. M., \& van Der Ham, J. L. (2013). A new Psammogammarus (Amphipoda: Eriopisidae) from anchialine pools on Exuma Cays, Bahamas. Zootaxa, 3700, 48-64.

Ledoyer, M. (1986). Faune mobile des herbiers de phanerogames marines (Halodule et Thalassia) de la laguna de Términos (Mexique, Campeche). II Les Gammariens (Crustacea). Anales del Instituto de Ciencias del Mar y Limnología, UNAM, 13, 171-200.
Lowry, J. K., \& Myers, A. A. (2013). A phylogeny and classification of the Senticaudata subord. nov. (Crustacea: Amphipoda). Zootaxa, 3610, 1-80.

Mejía-Ortiz, L. M., López-Mejía, M., \& Muñoz-Gómez, A. V. (2008). Crustáceos decápodos. In L. M. Mejía-Ortiz (Ed.), Biodiversidad acuática de la isla de Cozumel (pp. 225-238). Madrid: Plaza y Valdés.

Peart, R. A. (2004). A revision of the Cymadusa filosa complex (Crustacea: Amphipoda: Corophioidea: Ampithoidae). Journal of Natural History, 38, 301-336.

Peart, R. A. (2007). A review of Australian Cymadusa (Crustacea: Amphipoda: Ampithoidae) with descriptions of eight new species. Zootaxa, 1540, 1-53.

Peart, R. A., \& Hughes, L. E. (2014). Ampithoid amphipods from the South Pacific: Papua New Guinea, French Polynesia and New Caledonia. Journal of Natural History, 48, 739-861.

Suárez-Morales, E., \& Rivera-Arriaga, E. (1998). Hidrología y fauna acuática de los cenotes de la Península de Yucatán. Revista de la Sociedad Mexicana de Historia Natural, 48, 37-47.

Trujillo-Pisanty, E., Chávez-Solis, E. M., Solis-Weiss, V., \& Hermoso-Salazar, M. (2010). Peracarids (Crustacea: Malacostraca) from Cenote Aerolito, Cozumel Mexican Caribbean. Cahiers de Biologie Marine, 51, 177-180.

Yánez, G., Zarza-González, E., \& Mejía-Ortiz, L. M. (2008). Sistemas anquihalinos. In L. M. Mejía-Ortiz (Ed.), Biodiversidad acuática de la isla de Cozumel (pp. 49-70). Madrid: Plaza y Valdés. 